\title{
Influence of egg parasitic fungus, Engyodontium aranearum against root knot nematode, Meloidogyne incognita
}

\author{
M. Muthulakshmi*, B. Anita and S. Subramanian \\ Department of Nematology, Tamil Nadu Agricultural University, Coimbatore - 641003, (Tamil Nadu), INDIA \\ Corresponding author. E-mail: lakshminem@gmail.com
}

Received: November 14, 2014; Revised received: March 5, 2015; Accepted: March 15, 2015

\begin{abstract}
The indigenous egg parasitic fungal isolates, Engyodontium aranearum was evaluated for its nematicidal potential against root knot nematode, Meloidogyne incognita. The study revealed 53.75 per cent egg parasitization by the fungal isolate. Fungal colonies grew over the eggs and fungal hyphae penetrated the egg shells resulting in rupturing of egg shell layers, enzymatic digestion and empty eggs. The fungal culture filtrate was found to inhibit egg hatching by 83.42 per cent and caused upto 91.36 per cent juvenile mortality. This isolate also reduced the attraction of infective juveniles towards tomato root by 79.29 per cent. It seems to be a first report on the antinemic property of the fungus $E$. aranearum against root knot nematode, $M$. incognita and its effect was found comparable with Paecilomyces lilacinus which is known as an efficient nematode egg parasitic fungus.
\end{abstract}

Keywords: Engyodontium aranearum, Hatching, Mortality, Paecilomyces lilacinus, Parasitization, Root knot nematode

\section{INTRODUCTION}

Phytonematodes are being considered as serious limiting factor in the production of vegetables. Among the phytonematodes the root knot nematode, Meloidogyne incognita is reported to be responsible for 27.2 per cent yield loss in tomato (Jain et al., 2007). In the present scenario the biological control of pest including nematodes is gaining momentum due to ill effects of chemical nematicides and practical difficulties in adopting other methods of nematode management (Hague and Gowen, 1987). Recently an indigenous egg parasitic fungus isolated form potato in Ooty is was demonstrated as an potential bio candidate for the management of potato cyst nematode Muthulakshmi (2011).

The present study was programmed to study the influence and behavioural mechanism of the newly reported egg parasitic fungus on root knot nematode, $M$. incognita.

\section{MATERIALS AND METHODS}

Maintenance of monoculture of $M$. incognita: The seeds of tomato cv. Co 3 were surface sterilized by immersing in 0.1 per cent mercuric chloride for one minute and washed in distilled water for several times to remove the chemical. Five $\mathrm{kg}$ capacity pots were filled with autoclaved pot mixture (Red soil, sand and FYM at 1:1:1 ratio) and sterilized. Surface sterilized seeds were sown. After 25 days, the healthy seedlings were transplanted @ one seedling/ pot. Egg masses collected from $M$. incognita infested roots from the field were kept for hatching. The second stage juveniles were inoculated @ one $\mathrm{J}_{2} /$ gram of soil at 15 days after transplanting. The nematodes thus multiplied were maintained as pure culture. The nematodes required for the experimental purposes were harvested from this pure culture.

Maintenance of nematode egg parasitic fungi: The egg parasitic fungi, E. aranearum was maintained in the potato dextrose agar medium under room temperature $\left(28 \pm 2^{\circ} \mathrm{C}\right)$ for 5-7 days. The strains were maintained on potato dextrose agar (PDA) and sub cultured on the same medium at $28^{\circ} \mathrm{C}$ in dark for two weeks. The fungus culture thus obtained was identified based on morphological characters and further used in laboratory and glasshouse experiments.

Mode of action: The mode of action of the E. aranearum isolates against root knot nematode, $M$. incognita was studied as follows:

Assessment of egg parasitization in vitro: Egg parasitism was measured using an in vitro bioassay, following the protocol described by Abrantes et al. (1998). The test was performed using $E$. aranearum against $M$. incognita. Meloidogyne eggs were obtained from egg masses cultured on tomato grown in a temperature-controlled glasshouse. The $M$. incognita eggs were separated. Briefly, egg parasitic fungal cultures growing on potato dextrose agar were flooded with $5 \mathrm{ml}$ of sterile distilled water and aliquots of $0.2 \mathrm{ml}$ of fungal suspension were spread on to Petri dishes ( $9 \mathrm{~cm}$ diameter) containing 0.8 per cent water agar with antibiotics after two days of incubation at room temperature. 100 root knot nematode eggs were added to each plate. The Petri dishes were incubated at room temperature $\left(28 \pm 2^{\circ} \mathrm{C}\right)$ and after five days the numbers of parasitized eggs were counted under microscope. 
Four plates were maintained for each treatment in completely randomized design (CRD)

In vitro screening of $E$. aranearum culture filtrate against $M$. incognita

Preparation of fungal culture filtrate: Culture filtrate of the egg parasitic fungal isolates was prepared in Erlenmeyer conical flask $(250 \mathrm{ml})$ filled with $100 \mathrm{ml}$ of potato dextrose (PD) broth medium and then sterilized by autoclaving at $15 \mathrm{lbs}$ for $15 \mathrm{~min}$. After sterilization, at lukewarm stage $50 \mathrm{mg}$ of streptomycin sulphate was amended into the broth and mixed thoroughly. A fungal disc taken from the ten days old fungus was inoculated into the flasks containing medium and incubated at $28 \pm$ $2^{\circ} \mathrm{C}$ for 15 days. After stipulated time the contents were filtered through Whatman No.1 filter paper and were subjected to centrifugation at $15000 \mathrm{~g}$ for $15 \mathrm{~min}$. Centrifugation was done to remove the remaining hyphae and spores from the filtrates. The supernatant was designated as 100 per cent and from that required concentrations were prepared by adding distilled water for bioassay. The isolate of Paecilomyces lilacinus from Horticultural Research Station, Ooty was used as a biocontrol check in all the experiments. The effect of culture filtrates on egg hatching and juvenile mortality, attraction and penetration of RKN was studied in vitro in CRD.

Effect of $E$. aranearum on egg hatching ability of $\boldsymbol{M}$. incognita: One $\mathrm{ml}$ of the fungal suspension of different concentrations $(25,50,75$ and 100 per cent) was transferred to $5.0 \mathrm{~cm}$ diameter Petri dishes and one egg mass of $M$. incognita was placed in each Petri dish and incubated at room temperature. Egg mass placed in distilled water and autoclaved plain broth served as untreated control and $P$. lilacinus as standard check. The numbers of hatched juveniles were counted after 24, 48 and $72 \mathrm{hrs}$ of incubation. Four replications were maintained for each treatment in completely randomized design. The experiment was conducted under laboratory conditions.

Effect of $E$. aranearum on juveniles of $M$. incognita: One $\mathrm{ml}$ of the fungal suspension of different concentrations was transferred to $5.0 \mathrm{~cm}$ diameter Petri dishes. The $M$. incognita juveniles were transferred @ $100 \mathrm{~J}_{2}$ in each Petri dish and incubated at room temperature $\left(28 \pm 2^{\circ} \mathrm{C}\right)$. The juveniles placed in dishes containing sterile water and autoclaved plain broth served as control. The number of anesthetized nematodes were counted after 24, 48 and $72 \mathrm{hrs}$ of exposure. The experiment was conducted in a CRD and each isolate was replicated four times.

Effect of $E$. aranearum on attraction of $M$. incognita in tomato: The attraction or repulsion effect of egg parasitic fungal isolates $M$. incognita in vitro was studied by agar plate method. Melted water agar $(2 \%)$ was poured on the Petri dishes and kept in an incubator at a constant temperature of $27^{\circ} \mathrm{C}$ for $24 \mathrm{hrs}$. Three circles of 3,2 and $1 \mathrm{~cm}$ radius from the centre of Petri dish were drawn on the bottom of the Petri dishes denoting the regions of $\mathrm{a}, \mathrm{b}$ and $\mathrm{c}$ respectively. The surface sterilized tomato seeds (cv. Co 3) were grown in sterilized sand medium. The roots of seedlings with 7 days old were dipped with $E$. aranearum suspension containing $10^{8} \mathrm{cfu} / \mathrm{ml}$ and placed in the centre of each of the Petri dishes with untreated root bits and without root bits to serve as control. The juveniles of $M$. incognita was inoculated in each Petri dish near the periphery @ 100 nematodes $\left(\mathrm{J}_{2}\right)$ /plate and kept inside the plant growth chamber at the temperature of $28 \pm 2{ }^{\circ} \mathrm{C}$. The number of nematodes in the Petri plates was counted region wise at 24, 48 and $72 \mathrm{hrs}$ after their introduction into the plates.

Effect of $E$. aranearum on $M$. incognita penetration: An experiment was conducted to study the influence of $E$. aranearum on root penetration of $M$. incognita under glasshouse conditions. Tumbler cups were filled with steam sterilized fine river sand. Surface sterilized tomato seeds (cv. Co 3) were treated with egg parasitic fungal isolates@ of $10 \mathrm{ml}$ inoculum (containing 10 $80^{8} \mathrm{cfu} / \mathrm{ml}$ ) perkg seed. Then, the seeds were sown@ four seeds/ tumbler cup containing sterile sand. Untreated seeds served as control. The experiment was conducted in a completely randomized design and each treatment replicated four times. The cups were inoculated with $100 \mathrm{~J}_{2}$ of $M$. incognita one week after sowing. Plants from each cup were removed at an interval of one day starting from the day after inoculation (DAI) and continued upto 6 DAI. The roots were cut into small bits of $1 \mathrm{~cm}$ length, immersed in boiled lactophenol-acid fuchsin, destained in clear lactophenol and examined under microscope.

Statistical analysis: The data from various experiments were subjected to statistical analysis. The treatment means were compared by Duncan's Multiple Range Test (DMRT) (Gomez and Gomez, 1984). The package used for analysis was IRRISTAT version 92-1 by International Rice Research Institute, Biometrics Unit, Philippines.

\section{RESULTS AND DISCUSSION}

Screening for parasitization of root knot nematode eggs by egg parasitic fungi: Two egg parasitic fungi were tested for their parasitic activity against root knot nematode eggs. Among the two fungi the highest egg parasitization was observed with $E$. aranearum $(53.75$ $\%$ ) followed by $P$. lilacinus $(51.35 \%)$ compared to untreated control (Table 1). Fungal colonies grew over the eggs and the fungal hyphae penetrated the egg shells resulting in rupturing of egg shell layers, enzymatic digestion and empty eggs. Similar results were obtainted by Ayatollahy et al. (2008) where $P$. chlamydosporia var. chlamydosporia parasitized more than 70 per cent of the eggs in females and cysts on water agar. The fungus infected/colonized eggs were granular, dark brown and /or black in colour. Similar kind of egg parasitization was also reported by $P$. chlamydosporia in tomato (Sankarnarayanan et al., 2000) in M. incognita egg masses. Arora et al. (1990) observed the differences in the egg parastization ability among the 13 fungal isolates obtained from cysts in The Nilgiris. Highly significant differences 
were noticed between isolates on the ability to parasitize nematode eggs in vitro and to colonize the rhizosphere of maize (Esteves et al., 2009). In some cases the eggs became distorted even though the hyphae does not come in contact with the eggs, suggest a possible role of nematoxins. Nematophagous fungi may differ in their ability to penetrate the host cell by mechanical force and by producing various lytic enzymes (Stirling, 1991). Most of the colonized eggs were immature and therefore more susceptible to fungal invasion (Irving and Kerry, 1986). Mukhtar et al. (2013) revealed that the plant growth parameters and nematode infestations were recorded 7 weeks after inoculation. Both $P$. penetrans and $P$. lilacinus were equally effective and caused maximum reductions in number of galls, egg masses, nematode fecundity and build up as compared with $T$. harzianum and $P$. chlamydosporia. Our results indicate that application of antagonists can suppress galling and reproduction of M.incognita resulting in enhancement of plant growth.

\section{In vitro screening of $E$. aranearum against root knot} nematode, $M$. incognita

Inhibition in egg hatching: The two promising egg parasitic fungi were tested for their ovicidal effect against $M$. incognita. The experimental results revealed that the lowest egg hatching was observed in E. aranearum (40.14) followed by P. lilacinus (51.36) with 83.42 and $78.79 \%$ inhibition in egg hatching respectively at cent per cent concentration of culture filtrate after $72 \mathrm{hrs}$ exposure period (Table 2). Similar trend was observed upto 50 per cent concentration. The highest egg hatching was found in 25 per cent concentration at $72 \mathrm{hrs}$ after exposure period with value of 69.64 and 65.91 per cent eggs hatched in E. aranearum and $P$. lilacinus, respectively compared with 50 per cent concentration. The highest egg hatching was recorded in control (distilled water) (242.13) followed by 25 per cent concentration of Potato dextrose broth (197.32) after $72 \mathrm{hr}$ of exposure period. In the present study, the culture filtrate of the egg parasitic fungus $E$. aranearum significantly suppressed the hatching of root knot nematode eggs. Similar effects on hatching and juvenile mortality of cyst and root

Table 1. Parasitization of RKN eggs by egg parasitic fungal isolates.

\begin{tabular}{llc}
\hline S. & Treatments & $\begin{array}{c}\text { Per cent eggs } \\
\text { parasitized }\end{array}$ \\
\hline 1 & Engyodontium aranearum & $53.75^{\mathrm{a}}(7.37)$ \\
2 & Paecilomyces lilacinus & $51.35^{\mathrm{b}}(7.20)$ \\
3 & Sterile water & $0^{\mathrm{c}}(0.71)$ \\
4 & Control & $0^{\mathrm{c}}(0.71)$ \\
& $\mathrm{SEd}$ & 0.0296 \\
& $\mathrm{CD}(\mathrm{P}=0.05)$ & 0.0646 \\
\hline
\end{tabular}

Values are mean of three replications, Figures in parentheses are $\sqrt{n}+0.5$ transformed value Column figures followed by different letters are significant different from each other at 5 per cent level by DMRT

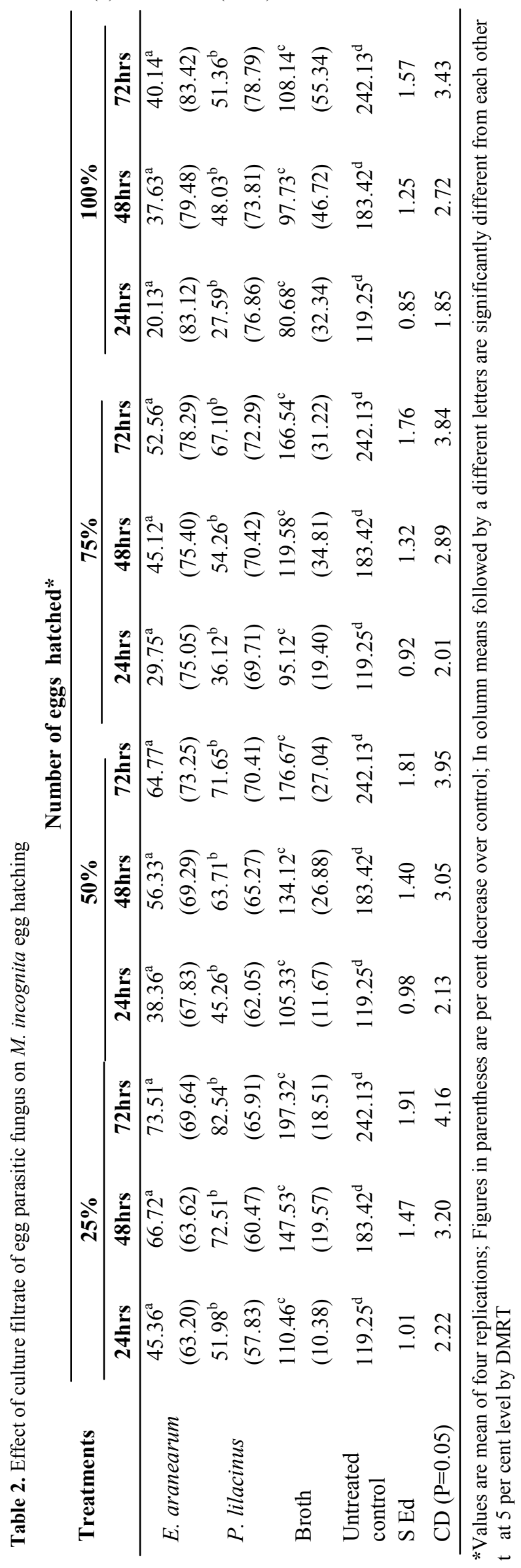


knot nematodes due to egg parasitic fungi was reported by Shinya et al. (2008) and Regaieg et al. (2010).A number of nematophagous fungi are known to have proteolytic and chitinolytic activities which cause alteration in eggs cuticular structure, changes in egg shell permeability or cause perforations in the cuticle which allows seepage of toxic metabolites into the eggs and cause physiological disorders (Webb et al., 1972; Jatala et al., 1985; Lopez -Llorca, 1990). These factors may have important role in the inhibition of egg hatching of root knot nematode. Consequently, the eggs (G. pallida) lose permeability and strength, becoming deformed and swollen (Tikhonov et al., 2002). During its primary infection steps, this fungus produces an alkaline serine protease that specifically degrades the proteinaceous outer-vitelline membrane of the eggs (Morton et al., 2004). Similarly, toxin-producing fungi affect nematodes by the production of nematicidal compounds (Dong et al., 2006). A scanning electron microscopy study of treated eggs showed severe alterations caused by the filtrate of isolate HR43 ( $P$. chlamydosporia) on $M$. incognita eggs, which appeared collapsed and not viable, suggesting the production of chitin-degrading enzymes or other active compounds (Regaieg et al., 2010).

Influence on juveniles of $\boldsymbol{M}$. incognita: The egg parasitic fungi were tested at $25,50,75$ and 100 per cent concentration at different exposure periods of 24, 48 and $72 \mathrm{hrs}$ interval against $M$. incognita juveniles. The results revealed that there was a gradual increase in the mortality of $M$. incognita juveniles with an increase in the concentration of different culture filtrates of egg parasitic fungi and its period of exposure compared to control (Distilled water). The isolate $E$. aranearum at 100 per cent concentration caused mortality ( 91.36 juveniles) at $72 \mathrm{hrs}$ exposure period and it was followed by $P$. lilacinus (86.56 juveniles) (Table 3). The E. aranearum (76.52) and P. lilacinus (68.37) at 75 per cent concentration were found to cause juvenile mortality at $48 \mathrm{hrs}$ exposure period. The least juvenile mortality was observed with $E$. aranearum (28.47) followed by P. lilacinus (23.52) at 25 per cent concentration after $24 \mathrm{hrs}$ exposure. The results revealed there was a positive correlation exists between per cent mortality of juveniles of $M$. incognita and $E$. aranearum concentration/time of exposure. The highest egg hatching was recorded in control (distilled water) (242.13) followed by 25 per cent concentration of potato dextrose broth (197.32) after $72 \mathrm{hrs}$ of exposure period. In the present study, the culture filtrate of the egg parasitic fungus $E$. aranearum significantly caused high juvenile mortality. Reddi Kumar et al. (2008a), Shinya et al. (2008) and Regaieg et al. (2010) revealed that lower number of root knot nematode and cyst nematode eggs hatched and higher juvenile mortality was observed using egg parasitic fungi.

Effect of culture filtrate of $\boldsymbol{E}$. aranearum on attraction of $M$. incognita juveniles: The isolate $E$. aranearum reduced juveniles attraction towards tomato root by 79.29 per cent over control and it was followed by $P$. 
Table 4. Effect of cent per cent culture filtrate of egg parasitic fungus on attraction of $M$. incognita juveniles in tomato.

\begin{tabular}{lcccccc}
\hline Treatments & \multicolumn{5}{c}{ Number of $\mathbf{J}_{2}$ attracted* } \\
\cline { 2 - 7 } & $\mathbf{2 4} \mathbf{~ h r s}$ & $\begin{array}{c}\text { Percent } \\
\text { decrease over } \\
\text { control }\end{array}$ & $\mathbf{4 8 h r s}$ & $\begin{array}{c}\text { Percent } \\
\text { decrease over } \\
\text { control }\end{array}$ & $\mathbf{7 2}$ hrs & $\begin{array}{c}\text { Percent } \\
\text { decrease over } \\
\text { control }\end{array}$ \\
\hline Engyodontium aranearum & $12.15^{\mathrm{a}}$ & 79.29 & $27.56^{\mathrm{a}}$ & 67.71 & $38.05^{\mathrm{a}}$ & 59.33 \\
Paecilomyces lilacinus & $17.84^{\mathrm{b}}$ & 69.59 & $33.97^{\mathrm{b}}$ & 60.20 & $44.17^{\mathrm{b}}$ & 52.79 \\
Broth & $55.76^{\mathrm{c}}$ & 4.96 & $80.27^{\mathrm{c}}$ & 5.96 & $88.49^{\mathrm{c}}$ & 5.43 \\
Untreated control & $58.67^{\mathrm{d}}$ & - & $85.36^{\mathrm{d}}$ & - & $93.57^{\mathrm{d}}$ & - \\
$\mathrm{SEd}$ & 0.48 & - & 0.72 & - & 0.81 & - \\
$\mathrm{CD}(\mathrm{P}=0.05)$ & 1.05 & - & 1.57 & - & 1.77 & - \\
\hline
\end{tabular}

*Values are mean of four replications; In column means followed by a different letters are significantly different from each other at 5 per cent level by DMRT.

lilacinus $(69.59 \%)$ at $24 \mathrm{hrs}$ of exposure period. The highest attraction was observed in control (distilled water) (93.57) followed by broth (88.49) after $72 \mathrm{hrs}$ exposure period (Table 4). The results revealed that the highest percentage of nematode attraction was found in $24 \mathrm{hrs}$ exposure period when compared to all other periods of exposure viz., 48 and 72 hrs. The nematode attraction towards host root decreased in all the treatments with increase in the exposure time. The results of the in vitro studies indicated that E. aranearum treated tomato seedlings reduced $M$. incognita attraction towards tomato roots compared to untreated control. The mechanisms of action may be due to the reduction of attraction and or repellence by production of metabolites and/or degradation of specific root exudates which control nematode behavior. Similar results were obtained by Dababat (2007) and Dababat and Sikoro (2007) who reported that the endophytes inoculated plants exudates reduced the total number of nematodes attracted to the inoculation area by upto 80 per cent over uninoculated control. The results indicated that the application of $P$. chlamydosporia enriched vermicompost at the rate of $50 \mathrm{~g} / \mathrm{m}^{2}$ was significantly effective in reducing the population of Meloidogyne incognita and increase the yield by 23.08 per cent on okra. (Chaya and Rao, 2012).

Effect of $E$. aranearum culture filtrate on $M$. incognita juveniles penetration in tomato root: The nematode penetration in tomato roots was observed upto 6 days after inoculation (DAI). The results revealed that level of nematode penetration was reduced by $87.50,85.57$, $83.10,77.02,65.43$ and 60.74 per cent in E. araneraum treated seedlings over control at 1, 2, 3, 4, 5 and 6 DAI respectively. It was followed by $P$. lilacinus (82.81, 80.60, 70.06, 66.77, 56.56 and 51.85) and differed in significantly $(\mathrm{P}<0.05)$ over control (Table 5). The results revealed that $E$. aranearum and $P$. lilacinus reduce had profound effect to the root penetration of $M$. incognita to tomato. The highest nematode penetration was observed in control (91.54) followed by broth (88.76). The results of the in vitro studies indicated that significant $(\mathrm{P}<0.05)$ reduction in penetration of $M$. incognita in E. aranearum treated tomato plants.
Earlier, Oostendrop and Sikora (1990) reported that the sugar beet cyst nematode, Heterodera schachtii penetration was decreased due to $P$. fluorescens treatment. The mechanism responsible for the reduction in nematode penetration was attributed to the ability of the bacterium to envelop or bind to root surface lectins, thereby interfering with normal host recognition by the nematode as also reported by Siddiqui and Mahmood (1995) and Kalaiarasan (2000) for root knot nematode.

\section{Conclusion}

The present study concludes that the egg parasitic fungus, $E$. aranearum is a potential biocontrol agent against root knot nematode, $M$. incognita. This fungus was found to parasitize nematode eggs leading to reduction in hatching and juvenile mortality. The studies also indicated that $E$. aranearum treated tomato roots attracted less $M$. incognita juveniles. The E. aranearum against root knot nematode was reported for the first time in India.

\section{ACKNOWLEDGEMENTS}

The authors are thankful to Societal Research Fellowship Scheme (WOS-B), Department of Science and Technology, who provided necessary funds operating the scheme work.

\section{REFERENCES}

Abrantes, I., Alho, L, Bourne, J., Carella, A., Ciantio, A., Clara, M.I.E., Davies, K., Franco, C., Hirch, P., Kerry, B., Lamberti, F., Lopez-Llorca, L., Mota, M., Santos, C., Sasanelli, N., Sorribas, J., Tzortzakakis, E.A. and Verdejo-Lucas, S. (1998). A workshop manual for research on Verticillium chlamydosporium as a biological control agent for root knot nematodes. IACR, Rothamsted, U.K.

Arora, R.K., Singh, D.K. and Joseph, M.M. (1990). Parasitization of potato cyst nematode eggs by fungi associated with cysts. Indian Phytopathology, 43: 294-295.

Ayatollahy, E., Fatemy, S. and Etebarian, H.R. (2008). Potential for biocontrol of Heterodera schachtii by Pochonia chlamydosporia var. chamydosporia on sugar beet. Biocontrol Science and Technology, 18: 157-167.

Chaya, M.K. and Rao, M.S. (2012). Bio-management of Meloidogyne incognita on okra using a formulation of 
Pochonia chlamydosporia. Pest Management in Horticultural Ecosystems, 18(1): 84-877.

Dababat, A.A. and Sikora, R.A. (2007). Effects of the mutualistic endophyte Fusarium oxysporum 162 on Meloidogyne incognita attraction and penetration on tomato. Nematology, 9: $771-776$

Dababat, A.A. (2007). Importance of the mutualistic endophyte Fusarium oxysporum 162 for enhancement of tomato transplants and the biological control of the root knot nematode Meloidogyne incognita, with particular reference to mode-of-action. Dissertation, Rheinische Friedrich -Wilhelms-Universitat, Bonn, Germany.

Dong, J.Y., Zhou, Y., Zhou, L.R., Zhu, L.L., Huang, R. and Zhang, K.Q. (2006). New nematicidal azaphilones from the aquatic fungus Pseudohalonectria adversaria YMF1.01019. FEMS Microbiology Letters, 264: 65-69.

Esteves, I., Peteira, B., Atkins, D.S., Magan, N. and Kerry. B. (2009). Production of extracellular enzymes by different isolates of Pochonia chlamydosporia. Mycological Research, 113: 867-876.

Gomez, K.A. and Gomez. A.A. (1984). Statistical Procedure for Agricultural Reasearch John Wiley and Sons, New York.

Hague, N.G.M. and Gowen. S.R. (1987). Chemical control of nematodes. In: Principles and Practice of Nematode Control in Crops. Brown, R.H., Kerry, B.R. (Eds.). Australia Academic Press, pp. 133-178.

Irving, F. and Kerry. B.R. (1986). Variation between strains of the nematophagous fungus Verticillium chlamydosporium Goddard II. Factors affecting parasitism of cyst nematode eggs. Nematologica, 32: 474-485.

Jain, R.K., Mathur, K.N. and Singh. R.V. (2007). Estimation of losses due to plant parasitic nematodes on different crops in India. Indian J. Nematol., 37: 219-221.

Jatala, P., Franco, J., Gonzales, A. and O'Hara. C.M. (1985). Hatching stimulation and inhibition of Globodera pallida eggs by enzymatic and exopathic toxic compounds of some biocontrol fungi. Journal of Nematology, 17: 501.

Kalaiarasan, P. (2000). Studies on the nematode pest of groundnut (Arachis hypogaea L.) and its management. M.Sc., (Ag.,) Thesis, TNAU, Coimbatore-3, India. pp 93.

Lopez-Llorca, L.V. (1990). Purification and properties of extracellular proteases produced by the nematophagous fungus, Verticillium suchlasporium. Canadian Journal of Microbiology, 36: 530-537.

Morton, O.C., Hirsch, P.R. and Kerry. B.R. (2004). Infection of plant parasitic nematodes by nematophagous fungi - a review of the application of molecular biology to understand infection processes and to improve biological control. Nematology, 6: 161-170.

Mukhtar, T., Arshad Hussain, M. and Zameer Kayani, M. (2013). Biocontrol potential of Pasteuria penetrans, Pochonia chlamydosporia, Paecilomyces lilacinus and Trichoderma harzianum against Meloidogyne incognita in okra. Phytopathologic Mediterranea, 52(1): 66-76.

Oostendorp, M. and Sikora. R.A. (1990). In vitro interrelationship between rhizosphere bacteria and Heterodera schachtii. Rev. Nematol., 13: 269-274.

Reddi Kumar, M., Sailaja Rani, J. and John Sudheer. M. (2008). Effect of culture filtrates of Paecilomyces lilacinus on the mortality and hatching of root knot nematode, Meloidogyne incognita. Indian Journal of Nematology, 38: 90-93. 
Regaieg, H., Ciancio, A. Raouani, N.H. Grasso, G. and Rosso. L. (2010). Effects of culture filtrates from the nematophagous fungus, Verticillium leptobactrum on viability of the root knot nematode, Meloidogyne incongita. World Journal of Microbiology and Biotechnology, 26; 2285-2289

Sankaranarayanan, C., Hussaini, S.S., Kumar, P.S. and Rangeshwaran. R. 2000. Biological control of Meloidogyne incognita (Kofoid and White, 1919) Chitwood 1949 on tomato by Verticillium chlamydosporium Goddard cultured on different substrates. Journal of Biological Control, 14: 39-43.

Shinya, R., Aiuchi, D., Kushida, A., Tani, M., Kuramochi, K. and Koike. M. (2008). Effects of fungal culture filtrates of Verticillium lecanii (Lecanicillium spp.) hybrid strains on Heterodera glycines eggs and juveniles. Journal of
Invertebrate Pathology, 97: 291-297.

Siddiqui, Z.A. and Mahmood. I. (1995). Management of Meloidogyne incognita race 3 and Macrophomina phaseolina by fungus culture filtrates and Bacillus subtilis on chickpea. Fundam. Appl. Nematol., 18: 71-76.

Stirling, G.R. (1991). Biological control of plant parasitic nematodes- Progress, problems and prospects. CAB International, Wallingford, UK. pp 282.

Tikhonov, V.E., Lopez-Llorca, L.V. Salinas, J. and Jansson. HB. (2002). Purification and characterization of chitinases from the nematophagous fungi, Verticillium chlamydosporium and V. suchlasporium. Fungal Genetics and Biology, 35: 67-78.

Webb, H.M., Ghafoor, A. and Heale, J.B. (1972). Protein and enzyme patterns in strains of Verticillium. Transactions of the British Mycological Society, 59: 393-402. 